\title{
Německy psané básně Pavla Országha Petr Kučera
}

\author{
KUČERA, P.: Pavol Országh's Poems Written in German \\ SLOVENSKÁ LITERATÚRA, vol. 68, 2021, no. 6, pp. 631-642 \\ DOI: https://doi.org/10.31577/slovlit.2021.68.6.4 \\ ORCID ID: 0000-0001-8919-6510
}

\section{Key words: Pavol Országh \\ Hviezdoslav, early work in German, \\ figurative system, intertextual \\ influences}

The article analyses the poems the Slovak poet Pavol Országh Hviezdoslav (1849-1921) wrote in German during his studies at the Evangelical Lyceum in Käsmark/Kežmarok (a town inhabited mostly by Germans at that time) in the late 1860 o. The author tackles his poetry in German in the broader cultural and historical context of the region, taking also in account his later work in Slovak. In addition to the thematic-motivic construction of texts Hviezdoslav wrote in German, the paper also deals with their system of imagery and states the dual nature of the poet's approach to depicting reality. The poems the article scrutinises were inspired by German poets from the late 18th and first half of the 19th centuries. Inspiration is most visible in the sensory concreteness - vividness - of natural sceneries in which space opens up and spreads in all directions in a surprising way. The highly personal tone of the poems and the fact that they address period social affairs lends the texts an even deeper social dimension. Hviezdoslav's active attitude towards the classical and Christian cultural and spiritual heritage also plays an important role in the poems addressed in this article.

Klúčové slová: Pavol Országh

Hviezdoslav, raná tvorba, nemecky

písané básne, bilingvizmus/

trilingvizmus, estetická hodnota, jambická metrická tendencia 

ěmecky psané básnické texty Pavla Országha jsou jasným svědectvím o polylingvismu a polyliterárnosti klíčové osobnosti slovenské poezie období realismu. Zároveň jsou i dokladem meziliterární dynamiky, která nebyla ve středoevropském kulturním areálu až do první světové války ničím neobvyklým. Také v tomto př́padě se potvrzuje známý fakt, že na hranicích kultur se originální nové tvorbě daří často lépe než v hloubi izolované a před cizími vlivy chráněné jedné kultury.

Období německy psané poezie zahrnuje roky studia P. Országha na evangelickém lyceu, respektive gymnáziu v Kežmarku, kam přišel ve školním roce 1865/1866 do kvarty po třech letech strávených na gymnáziu v mad'arském Miškovci. V Kežmarku nastoupil do německé tř́dy (nižší gymnázium bylo německé, zatímco vyšší bylo mad'arské). Käsmark/Kežmarok měl mezi městy, jimž dominovali řemeslníci a obchodníci přišlí ze Saska, do značné míry výjimečné postavení. Německým kolonistům se díky privilegiu, které jim udělil Štěpán V., podařilo utvořit značně autonomní Společenství spišských Sasů (kodifikovali vlastní právo, Zipser Willkühr, od 17. století používalo město Käsmark saské právo, Sachsenspigel). Až do konce 19. století žilo ve městě na tři čtvrtiny Němců, velmi početná a aktivní zde byla také židovská obec, jejíž členové byli nejen obchodníky, zlatníky a dalšími řemeslníky, ale i učenci a umělci. Kežmarské školství se rozvíjelo již od 14. století, v 19. století mělo zdejší lyceum nadregionální význam a přitahovalo nadané studenty i z okolních zemí. Unikátní (nejen počtem svazků, ale i šírí tematického záběru) byly v době studií P. Országha kežmarské knihovny (lycejní a městská) - výrazně se zde projevil protestantský a židovský důraz na knižní vzdělanost a literární kulturu. Kulturní atmosféru města dotvářel živý spolkový život (blíže Online-Lexikon zur Kultur und Geschichte der Deutschen im östlichen Europa).

Sílící mad'arský útlak měl za následek nejen ztrátu oprávnění k provozování lycea (bylo jen vyšším mad'arským gymnáziem), ale zejména jisté spojenectví slovenských studentů s většinovými spišskými Sasy, kteří se navzdory svému počtu postupně stávali znevýhodňovanou „menšinou“. V této národnostně zjitřené atmosféře vznikal Hviezdoslavův celoživotní zájem o německou literaturu, o čemž svědčí nejen jeho rané německy psané básnické i esejistické texty, ale především pozdější př̀klady německých klasiků do slovenštiny. $V$ průběhu let strávených v Kežmarku došlo k postupnému vnitřnímu přerodu mad'arsky a německy píšícího studenta ve slovenského básníka.

Třebaže němčinu zažil P. Országh jako vyučovací předmět jen v kvartě (od kvinty byla na vyšším gymnáziu vyučovacím jazykem mad'arština), udivuje jeho schopnost osvojit si němčinu v poměrně krátké době na takové úrovni, že v závěru studia již psal německé básně, které jsou zajímavé nejen tematicko-motivickou výstavbou a obrazností, ale mají - na rozdíl od začátečnických pokusů - dobrou úroveň i z hlediska metrického a jazykového. Ve svých vzpomínkách zmiňuje Hviezdoslav svého učitele němčiny v kvartě, který přirovnal básníkův veršovaný pokus na zadané téma školní práce (Im Frühling) k básnění mladého Goetha: $z$ veršů, které si Hviezdoslav při vzpomínce vybavil, je patrné goethovské zalíbení v dynamickém a personifikovaném zobrazování pruírodního dění: „Die 
ruft: erwach', erwach'..." (Pražák 1955: 93). ${ }^{1}$

Országhovy německy psané básně (a školní eseje) z dochovaných rukopisů shromáždil, edičně připravil a úvodní studií Nemecké básnické pokusy Pavla Országha-Hviezdoslava opatřil pro publikování ve sborníku Matice slovenské $L i$ terárny archív 10/73 Ervín Lazar. ${ }^{2} \mathrm{O}$ potřebný nadhled nad německy psanou poezií P. Országha usiloval L'udovít Petraško (Petraško 1975). Nejnovějšími nálezy Hviezdoslavových slovensky psaných raných básnických textů se v širších kulturně historických souvislostech zabývá Anna Zelenková (Zelenková 2017).

L'. Petraško si všímá ve studii Interpretácia nemeckej poézie P. O. Hviezdoslava jednak tendencí barokních (všudypřítomný protiklad vysokého a nízkého) a tendencí romantických (smutek bez zjevné přičiny), jednak podob lyrického subjektu, který často splývá se subjektem autorským. Zmiňuje také (dosud nedoloženou) typologickou souvislost s lyrikou německého romantického básníka a prozaika Josepha von Eichendorffa (Petraško 1975:158). Podobně jako E. Lazar je i L'. Petraško kritický k jazykovým, metrickým a rýmovým nedostatkům německých textů P. Országha (Petraško 1975: 154-156). U zmínek o vlivu křestáanství na jeho tvorbu nerozlišuje mezi katolicismem a protestantstvím - tuto diferenci však nelze pominout ani v rovině teologické či etické, ale ani estetické. Již barokní poezie se rozdělila na linii katolickou (tíhnutí k mysticismu, výrazová bohatost, usouvztažňování rozmanitých kulturních obsahů, extrémní oscilace mezi krajními póly etickými i estetickými) a protestantskou (adorování askeze, oslabení vizuální obraznosti, důraz na niternost proživání a s tím související odklon od př́lišné extatičnosti).

Katolický ráz poezie i prózy J. von Eichendorffa je v rovině etické (a zčásti i estetické) pro P. Országha těžko přijatelný, ale okouzlení z textů německého romantika se pravděpodobně týkalo hlavně virtuozního nakládání se suprasegmentálními jevy (rytmus, větná melodie, eufonie) a podob (sebe)prožívání moderního subjektu. S Petraškovou charakteristikou lyrického subjektu v Országhových německých básních lze však plně souhlasit:

„Citlivý a melancholický pozorovatel' diania okolo seba sa zamýšla nad behom sveta a plynutím času. V prírode nachádza paralely pre vyjadrovanie svojho vnútorného rozpoloženia, ktorému dominuje bližšie nepomenovaný smútok. S tým súvisí častý motív jesene, večera, hviezdnatej noci i smrti. Cez a poza prírodu sa básnik usiluje pocítit univerzum, nekonečno, ktoré ho pritahuje a súčasne v ňom vzbudzuje posvätnú hrôzu. V lexike nachádza táto tendencia svoj výraz v priam hypertrofii abstraktných pomenovaní ako Hoffnung, Trauer, Wehmut,

1 Albert Pražák zde zaznamenává Hviezdoslavovu vzpomínku na profesory německé třídy gymnázia, kteří mladého básníka nejen chválili, ale také mu podporami umožnili bydlení v soukromém domě po pastorovi Kuncovi, aby při svém básnění nebyl nikým rušen.

2 E. Lazar uvádí následující německé básně: Der Landmann, Der Hirt, Verlang' ich nicht!, Beim Strome, Jenseits, Mein Vertrauen, Das Gefühl, Die Tage, Die Felsenrose, Der größte Schatz, Der Stern, Am Abend a básnické zlomky (rukopisy těchto básní a zlomků uchovává Literárna expozícia P. O. Hviezdoslava Oravského múzea v Dolnom Kubíne), dále rozsáhlou epickou skladbu Der sterbende Schwan (rukopis uchovává Literárny archív Slovenskej národnej knižnice) a připojuje školní eseje a překlady dvou básní (Uhland, Goethe). O jejich umělecké hodnotě nemá vysoké mínění, o čemž svědčí i fakt, že je v názvu své studie označuje jako „básnické pokusy“. Podrobně se zabývá také metrickými a gramatickými nedostatky Országhových německy psaných textů (Lazar 1973). 
634 Plage, Labe, Labsal, Ewigkeit. Predmetom apostrofovania lyrického subjektu sú ludia, resp. ludstvo a boh ako prostriedky pri hladaní životných istôt. Súbežne sa tu manifestuje láska k domovine“ (Petraško 1975: 149-150).

Již v rané básni Beim Strome (U řeky) vnáší P. Országh do přírodního děje motiv smutku z opouštění domoviny. Lyrický subjekt, jemuž se zdá, že řeka tekoucí k hranici vzlyká při loučení, prosí řeku, aby nezapomněla na své rodiště. V zárodečné podobě se zde objevuje budoucí důležité téma, jímž je rozporuplnost složitých emocí (,die Trauer der Liebe“ - „smutek lásky“):

„Stille mit Sanftmut eilst an die Grenzen des unsrigen Landes, O Strom! - und bald verließ'st liebes dein ländisches Haus.

[...]

O ja! du kränkst dich, seh' ich die Größe wohl deiner Wehmut

Und hör' tief im Schoß Schluchzen bei deinem Abschied.

Lebe wohl, o Strom! allen auflangen und weiten Wegen

Zwischen den Bergen und Flur häufiggedenke unser!" (Lazar 1973:282-283)

Vědomí neustálé oscilace mezi okamžiky štěstí a bolesti v rozbouřené emocionální hladině ztvárňuje mladý básník evokací večerní nálady v básni $\mathrm{Am}$ Abend (Večer). Obraz zapadání slunce ve vlnách moře, zvuk zvonu bijícího na věži a růžovění mraků tvoří malebnou scenérii k rozehrání základní problematiky, jíž je psychické rozpoložení lyrického subjektu, jak signalizují již první dva verše („In tiefe Still' und düstre Sorge / Sank ich und sitz am Fensterrand“ - „V hlubokém ztišení a temné starosti / klesl jsem a sedím na kraji okna“). Dynamické př́rodní děje při západu slunce zaplňují široký prostor, do smyslově sugestivního dění se zapojují abstrakta vyjádřující emoční i duchovní stavy:

\section{„Lang schienen schon die letzten Strahlen \\ An Wolk' mit Rosenfarb' gestreut. \\ Die Sonne ruft in Meeres Wellen, \\ Der Abend seine Tränen weint.}

Kein Ton ist mehr, all's still geworden,

Nach Müdigkeit selg' Träume lebt. -

Mein Herz wacht nur - bald in dem Sturme

Gefühles, - bald im stillen ebet schwebt" (Lazar 1973: 288).

Významové dění obou básní se odehrává v protikladu k ustalujícím se rozporuplným emocím, které směřují do sféry vysokého (vlastenecké cítění a postoje spjaté s protestantskou morálkou). Zároveň se zde objevují reflexe psychologické problematiky - hluboce znepokojený (ve své podstatě již moderní) subjekt se ocitá ve vnitřním konfliktu s předem zformovanými hodnotami.

Tíha smutku z opuštění domoviny je tématem básně Jenseits (Na druhé straně), která blíže osvětluje hodnotu lásky k vlasti: ta je prostorem, v němž utrpení 
slábne a člověk zbavený smutků vnitřně roste v blaženosti. ${ }^{3}$ Oslavu domoviny 635 doplňuje slib básnického mluvčího, že vlast čelící protivenství nikdy neopustí. Láska k vlasti je zobrazována pomocí instrumentária křestanských motivů a symbolů - v Országhově poezii je často začleňována do sféry sakrálního, což zesiluje paradoxnost básníkovy niterné pasivity (na jedné straně povinnost pokory vioči posvátnému, na druhé straně nutnost aktivní podpory vlasteneckých snah):

„Bei dir vergeß' ich alle meine Plagen,

Mein Eigentum: mein' Qual und Pein,

Du nimmst ab meines Kopfes trüben Schleier

Und gibst nur Seligkeit allein.

„Ich laß' dich nicht-du freiheitsvolle Allheit,

Du höhere Stufe - o Phantasie!

Was ist die Erd', das Jammertal des Lebens, Ich will dich, denen bleibe sie“ (Lazar 1973: 283).

Druhá významová linie ze sféry hodnotově vysokého obsahuje prožitky spirituální povahy. Objevuje se v básni Mein Vertrauen (Má důvěra), ve které dosavadní důvěru pouze v Boží vedení doplňuje obrat také $k$ dobrým lidem - právě tyto „horlivé duše“ („,eifrige Seelen“) pomáhají utvářet cestu, po níž se lyrický subjekt vydává. Za pozornost stojí dialogický ráz básně, díky němuž nemá text povahu kazatelského předávání duchovní či jiné zkušenosti, ale je oslovením věřících i poděkováním za jejich pomoc. Čtenář se tak stává přímým účastníkem emocionálně silné situace, zrodu touhy po důvěrou prodchnutém společenství, bez něhož by byl duchovní život křestana neúplný:

„Was sag ich wieder! - mein Vertrauen

Euch gab ich, gute Menschen, euch;

So helfet mir mein' Weg zu bauen,

Wenn redet zu: den Wunsch erreich ich.

Vertröstet mich, eifrige Seelen!

Gott und ihr mein Vertrauen seid-

Zum Bäumchen auch den Pfahl dar'm geben,

Daß's nicht der Wind abbbricht so leicht" (Lazar 1973: 284).

Reflexi naděje pak přinášejí básně Verlang ich nicht! (Nežádám!) a Der größte Schatz (Největší poklad). První z nich přesouvá oblast př́ání a snů do sféry Boží vưle, a proto nežádá jejich splnění, ale pouze prosí o jiskru naděje. Pokoru manifestující lyrický subjekt klade důraz na trpělivost srdce jakožto věčnou povinnost:

3 Pocity smutku a osamění se v raných básních ještě neobjevují v explicitní podobě, ale jsou zde patrné jako stopy budoucího důležitého tématu. Bliže k tématu samoty u Hviezdoslava Šmatlák 1979: 190. 
„Verlang' ich nicht! Verlang' ich nicht!

Daß mein Traumreich ganz in Erfüllung geh'.

Es tuet meinem Herzen auch nicht weh;

Es Gott! - nach deinem Willen spricht.

Es ist genug! Verlang' nichts mehr'

Ein' Funk' von meiner Hofnung nur o Gott!

Weil ich erfuhr, ich weiß es gut daß oft

Ein Funk' gebar ein heuers Meer" (Lazar 1973: 282).

Druhá báseň (Der größte Schatz) vytváří zajímavé napětí směřování k pointě, kterou v posledním verši tvoří pojem naděje (Hoffnung), ta je největším pokladem, který pomáhá překonávat útrapy na životní cestě od mládí až ke stáří. Právě naděje také odívá i srdce člověka stojícího nad temným hrobem jiným vnímáním skutečnosti, jakousi „novostí“ („Neuheit“). Od pouhého cvičení ve zbásňování poselství evangelistů a apoštolů se tato (ale i jiné Országhovy básně na podobná témata) liší snahou o vlastní, dynamickou, akusticky i vizuálně fundovanou obraznost umístující abstraktní dění do konkrétních obrazů:

„Jeder Mensch hat tief in seinem Herzen

Ein Eigentum sehr tief verhüllt,

Das ihm in Trauer und in Schmerzen

Die Brust mit lauem Trost erfüllt;

Und wenn die Donnerstürme über ihn wehn,

Erblickt sein Schatz und bleibt begeistert stehen" (Lazar 1973: 287).

Význam náboženského cítění a probuzení (v duchovním smyslu), které osvobozuje od pozemských sklonů, rozvíjí báseň Die Tage (Dny). Brzké probuzení k náboženské víre je zde chápáno jako podmínka radostného života, nebot' umožňuje věřícímu člověku vnímat mladost světa:

„Vergeße deiner irdischen Neigung,

Die dich stark fess'lt, zerreiß' die Macht,

Nur der fühlt Freud', der früh erwacht

Und sieht die Welt wie los, wie jung“" (Lazar 1973: 284).

V básních s tematikou prŕrody a práce pastýřu či rolníků je P. Országh ponořen do mezilidských a společenských vztahů víc než do prožitku krásy a rozmanitosti horské přírody Vysokých Tater a okolí, třebaže dokáže evokovat i její atmosféru. Báseň Der Hirt (Pastýŕ) je oslavou volnosti pastýřského života, který se odehrává uprostřed horské prŕrody. Ve stínu košatých stromů může unavený pastýř spočinout za zvuků písně zurčící bystřiny a odevzdávat se snům. Objevuje se zde básníkův častý motiv nízkosti země, kterou pastýř pohrdá, když se ve snění pozvedá k výšinám. Motiv domoviny je zde spojován s horami, příroda je zeleným chrámem:

„Mein Weg zieht hoch in Berge,

Hoch über niedres Land, 
Ich steig' aufohn' Beschwerde,

Dies' ist mein Vaterland.

[...]

Wenn müd' bin, leg' mich nieder,

Zum saus'nden Berges Strom,

Und hör' die süßen Lieder

In meinem grünen Dom" (Lazar 1973: 281-282).

Těžká práce rolníka je tématem básně Der Landmann (Rolník). Bezútěšnost jeho každodenní dřiny od svítání po soumrak ${ }^{4}$ vyvažuje zvuk večerních zvonů a radostného vítání v kruhu rodiny, pro kterou žije. Velice osobní tón vtiskuje textu autorova modlitba $\mathrm{k}$ Bohu, aby neponechal rolníkovu naději nevyplněnou a daroval mu radostný život, nebot tímto rolníkem je básníkův otec:

„Ja sein Glück alles scheinet,

Die kleine Familie

Von Freude Tränen weinet;

Er lebt allein für sie. -

Schick aufihn o Gott Segen,

Sein'Hoffnung laß nicht leer,

Gib freudevolles Leben,

Mein Vater ist mir er!" (Lazar 1973: 281)

Nejrozsáhlejší (dvanáct osmiveršových strof) z Országhových německých lyrických básní je Die Felsenrose (Skalní růže), která pomocí př́rodních motivů tematizuje existenciální problematiku uvadání a zanikání všeho živého. Nádherně zbarvená květina roste vysoko v horách, unavený lyrický subjekt se chce občerstvit její vůní. Růže vyhledávaná včelami roste bez zásahu lidské ruky, stará se o ni sama příroda - před vyschnutím ve slunečném žáru je chráněna večerní rosou. Pak nastává neúprosný proces vadnutí, usychají okolní květy, růže bledne. Poslední květy zvadnou, nastává ticho a vše spěje k podzimu. Mluvčí básně si bolestně uvědomuje neodvratnost také svého vlastního zániku. Básník využívá své oblíbené křest'anské motivy jako milost (Gnade, Huld), soucit (Erbarmung), nebeské (himmlisch), ale také věčné světlo (der Sonne ew'ges Licht) a radostnost (Erfreuung) ročního období rozkvětu (des Jahres ... Blütezeit):

„Sie hört', begann sich neigen,

Ihr' Gnade ist's und Huld,

Ringsum die Blumen schweigen,

Bewund'ren ihr' Unschuld. -

[...]

Für alle sind die Strahen,

Der Sonne ew'ges Licht,

4 Vědomí rozporuplnosti venkovského života, který má své idylické i tragické momenty, sice ještě není v této době u P. Országha rozvinuté do podoby známé z jeho zralých slovenských děl (Šmatlák 1999: 204), ale jisté náznaky v podobě motivu těžké a bezútěšné dřiny rolníka lze v básni Der Landmann vystopovat. 
Erfreuung, Blütenzeit;

Doch fühlt dazu ein Wahres:

Die Lieb' und Herrlichkeit" (Lazar 1973: 285).

Obvyklá jambická vzestupnost Orsághových německých veršů získává v této básni hlubší smysl směřování vzhưru. Vzhledem ke vzrušenému tónu básnického mluvčího př́liš neruší ani (gramaticky nekorektní) vynechávání členů, které dokládá interferenci slovenštiny a je pro ranou německou tvorbu P. Országha typické. Oproštěním se od vlasteneckých a - navzdory př́tomnosti křestanských motivů - i náboženských apriorismů získává báseň Die Felsenrose poetické kvality, díky nimž se posouvá od začátečnických pokusů směrem ke zralejšímu uměleckému usilování.

V lyrických básních P. Országha je patrná inspirace některými rysy tvorby německých básníků z konce 18. a první poloviny 19. století. Je to v prvé řadě smyslová konkrétnost, plasticita př́rodních scenérií, v nichž se prostor nebývale rozšiřuje do všech směrů a spojením s velmi osobním tónem a zájmem o společenské dění získává ještě i hlubší sociální dimenzi. Nemalou roli sehrává básníkův aktivní přistup k antickému a křestanskému kulturnímu a duchovnímu dědictví.

V meziliterárních souvislostech je třeba také uvažovat o otázce původu jambické metrické tendence v Országhově básnění šedesátých a sedmdesátých let 19. století. Stanislav Šmatlák formuloval hypotézu o vlivu českých básníků-májovců (Šmatlák 1961: 80). P. Országh však přichází do bližšího kontaktu s českou literaturou a kulturou až v sedmdesátých letech; důkladně a podnětně se básníkovým vztahem k české kultư̌e ve své monografii zabývá Ján Gbúr (Gbúr 1998). Pro májovce má podstatný význam německá poezie (zejména Johann Wolfgang von Goethe a Heinrich Heine). V německy psaných verších lze vytvořit jambickou metrickou tendenci podstatně snadněji než v češtině nebo ve slovenštině, to znamená v jazycích, které mají pevný slovní přízvuk na první slabice taktu.

Akcentologické poměry němčiny (přízvuk na základovém morfému u německých slov, možnosti nepř́izvučných předpon, ale i respektování původního přízvuku u slov převzatých např́klad z francouzštiny či italštiny) se v češtině nebo ve slovenštině napodobují velmi obtížně (pro srovnání lze uvést problémy českého básníka Karla Hynka Máchy při přechodu z němčiny do češtiny, kdy jambickou tendenci veršů Máje „chránil“ před sklouzáváním do trochejského spádu rozdělováním veršů na poloverše a opětovným umístováním jambických předrážek). P. Országh nepotřeboval zprostředkování poezií českých májovců, protože se s jambickou metrickou tendencí seznamoval přímo prostřednictvím německé poezie (a aplikoval ji ve své vlastní německy psané tvorbě v šedesátých letech).

Ve své překladatelské činnosti se slovenský básník soustředil u německé literatury na tvorbu J. W. Goetha (1749-1832), Friedricha Schillera (1759-1805) a Ludwiga Uhlanda (1787-1862). Hviezdoslavovými překlady z německé poezie (Sobranéspisy básnické jim věnují 14. svazek; Hviezdoslav 1931) se nejprve zabýval E. Lazar z hlediska převážně lingvostylistického (Lazar 1955). Celé překladatelské 
dílo P. O. Hviezdoslava pak analyzoval Viliam Turčány ve studiích zaměřených 639 na poetologické, zejména verzologické aspekty (Turčány 1960, 1961).

Nezanedbatelnou roli v Hviezdoslavově básnické tvorbě sehrál i H. Heine (1797-1856). Goethe a Heine jsou - podobně jako je tomu v české poezii druhé poloviny 19. století - katalyzátorem básnického vývoje i mladého P. Országha. Zatímco v Goethově případě jde o vzhlížení ke kanonizované kulturní hodnotě, Heine je pro něho vzorem spíše v rovině dokonalého zvládnutí stylu lyrických básní. „Podvratná“ funkce ironie, kterou Heine neváhá používat i k bourání nejvyšších model, je pro Országha těžko akceptovatelná.

Goethe je sice předmětem uctívání, nikoli však pasivního napodobování: německý básník ukazuje svým rozsáhlým dílem P. Országhovi různé možnosti poezie vysokých nároků a zprostředkovává mu také bohatství evropské a orientální kultury. ${ }^{5}$ Orientace P. Országha na vysokou kulturu, na poezii ideálních nároků se projevuje jasným hodnotovým rozvržením na ose vysoké - nízké, které se promítá i do makroprostoru vesmíru. Nejnázorněji je tento rys jeho tvorby patrný v básni Der Stern (Hvězda) z tematického okruhu, který je pro budoucího slovenského básníka Hviezdoslava velmi důležitý:

\section{„Am Himmel schwebt ein Haufe Stern, Und blickt in seinem Zauberglanz- \\ Kein' Wolke ziehrt sich, nur im Fern \\ Dein Norden krönt ein heller Krantz.}

So schön, klar ist der Horizont,

Die Erde unten dunkles Grab-

Es schützt uns der da oben wohnt,

Der schaut mit wachem Aug' herab.

[...]

Es blickt der Stern, und gleich schwand

Verloren all' die Heiterkeit,

Der schimmert doch, - winkt mit Strahlhand,

Eilt her! Ich bin die Ewigkeit" (Lazar 1973: 287-288).

Základní hodnotový protiklad tvoří kouzelně zářící hvězda vysoko na nebi, odkud na nás shlíží Bůh, který nás chrání, a dole se nacházející země, jež je temným hrobem. S nebeskými objekty se pojí výrazně kladné hodnoty (měsíční nádhera, hvězda představující věčnost, ve výši vše žije a bdí). Snaha o zachování pravidelného rytmu je patrná i z faktu, že se v každé strofě vyskytují elidované gramatické tvary. Přehledné rozvržení hodnot zasahuje i pozici lyrického subjektu, svou účastí a schopností zprostředkovat úchvatné děje má i básník svůj podíl na idejích krásna a dobra.

Podobně jako Goethe a Schiller je i P. Országh básníkem idejí (ve smyslu Ideendichtung), o čemž svědčí mimo jiné i jeho esejistické úvahy o otázkách

5 J. W. Goethe poutá i překladatelskou pozornost P. O. Hviezdoslava od studentských let až po zralé tvůrčí období. Již v kežmarském období přeložil mimo jiné Goethovu slavnou báseň Wandrers Nachtlied (respektive její část Über allen Gipfeln). 
640 dobrého stylu v textu Die Notwendigkeit eines guten Stils (Nutnost dobrého stylu). Dobrý styl představuje pro něho velkou hodnotu, je nepostradatelný a důležitý dokonce nejen pro adepta humanitních nauk, ale i pro toho, komu se zdá, že ho nepotřebuje, protože je vázán ke svému řemeslu. Dobrý styl se pojí s pravdivostí a harmoničností, opakovaně je kladen do souvislosti s vědeckým poznáváním nejen vnější reality, takové, jaká skutečně je, ale i obtížného poznávání vnitřního světa člověka: „Da die Ordnung der inneren Welt der Menschen, die man schriftlich darzutun, vor die Augen stellen will, wie sie ist und wie sie erscheint, nicht die leichteste Seite der Wissenschaft ist. Denn viele versuchen es, ohne auf die Harmonie einen gewissen Nachdruck gelegt zu haben; so ist es allerdings notwendig die Aneignung eines guten Styls, der dahin trachtet, wie man zu Worten komme das, was man innerlich fühlt, was das Herz schmerzt oder es erfreut, in rechten Ausdrücken zum Lichte emporheben könne" (Lazar 1973: 294-295). ${ }^{6}$

Vnitřní rozporuplnost básnického směřování P. Országha je harmonizována právě snahou o vysoký styl a soustavné vztahování se k nezpochybnitelným hodnotám lidské kultury. S úsilím o pohyb ve sféře vysoké kultury a vysokých mravních nároků souvisí i sklon P. O. Hviezdoslava k mýtotvorbě (včetně budování mýtu sebe sama). Na automýtotvorný proces u Hviezdoslava upozorňuje Valér Mikula, který rozlišuje Hviezdoslavův „metamýtus“ a „automýtus“, s tím, že oba typy časem splynuly, když „metamýtus“ absorboval mnohé preformace „automýtu“, takže je lze již jen těžko rozlišit (Mikula 1997: 49): „Je zjavné, že gymnaziálne sugescie základne určili obraz básnika, ako si ho modeloval mladý Országh. Tento vzor s rastúcou skúsenost́ou Hviezdoslavovou nadobúdal presnejšie kontúry, bol dopíňaný, ba prešiel - avšak bez väčšej ujmy - i búrlivejšou peripetiou Banšellovho vplyvu [...]. Až do konca básnikovho života sa však jeho vzor, model básnika trvalo vyznačoval afirmatívnym nadväzovaním na tradíciu, na klasiku [...]. Napíňanie vzoru, celistvého modelu básnika, ktorý si sám vytvoril, stane sa motiváciou Hviezdoslavovho celoživotného úsilia“" (Mikula 1997:51).

Vrchol Országhovy německy psané poezie představuje rozsáhlá (142 veršů) epická skladba Der sterbende Schwan (Umírající labut'). Z množství ptačích symbolů (orel, čáp, slavík, holubice, albatros, krkavec a jiné) poutá labut již od starověkého Řecka trvalou pozornost básníků (i později slovensky píšící básník Hviezdoslav si ptačí symboly oblíbil). Vedle věrnosti labutího páru, krásy, ladnosti pohybů je to právě záhadný předsmrtný zpěv, co probouzí fabulační fantazii. P. Országh má ve svém německém textu ambici nejen naplnit dějovou osnovu staré báje rytmy a obrazy svého básnického umění, ale posunout skladbu do další významové roviny - v malebných scenériích reflektovat touhu moderního člověka-umělce po dokonalosti, kterou v básni symbolizuje krása ptačího zpěvu.

Po úvodní expozici noční přírody, ve které labut' žije štastně, přichází emocionální zlom: růžový keř se stal domovem výjimečného pěvce-slavíka, vůči němuž labut' pocítí závist. Labut' se obrací k bohu umění Phöbovi s prosbou o získání schopnosti zpívat jako slavík. Phöbus prosbu vyslyší s podmínkou, že zpěv labutě bude moci být tak krásný pouze těsně před její smrtí. Právě před smrtí začne labut'

6 Ve svých studentských esejistických úvahách o stylu vychází P. Országh sice z tradičních doporučení příruček rétoriky a stylistiky, ale zároveň již zdůrazňuje vedle jazykově stylistických hodnot (jasnost, výstižnost výrazu) i etické momenty (opravdovost, upřímnost). 
nádherně zpívat a pěje tklivou píseň až do svého skonu. Za rozednění je vidět na vodě mrtvé tělo labutě, jemuž slavík zazpívá smuteční píseň.

Országhovo tíhnutí k vysoké kultuře se v básni projevuje nejen antickými motivy, postavou slavíka-operního pěvce, ale také propracovanou dějovou gradací, patetickým tónem, ale i archaizujícími lexikálními a gramatickými jevy, díky nimž připomíná - nepochybně záměrně - německou veršovanou epiku $\mathrm{z}$ konce 18. století. Epickou skladbu Der sterbende Schwan však nelze přiřazovat $\mathrm{k}$ rétoricky mnohomluvným historizujícím textům adoračního rázu. Již samotné téma je závažné: na klasicistním půdorysu reflektuje autor existenciální problém propastnosti umělecké existence, ve které se za dosažení mimořádné krásy platí cenou nejvyšší, pozemským životem.7 Zvládnutí vysokého stylu zde P. Országh prokazuje také méně nápadnými poetologickými charakteristikami, jakými jsou zejména stylová homogenita, jemné odstínění proměn nálady, stř́íání rytmu i v rámci jednoho verše, intonační pestrost či udržování osobního kontaktu „vypravěče" se čtenářem.

\section{Závěr}

Německy psané básnické texty P. Országha z jeho kežmarského období směřují záměrně do sféry vysokého jak v gramatické a lexikálně sémantické rovině (knižní až archaické tvary, poetismy) a v rovině tematicko-motivické výstavby, ale také v systému obraznosti. Jevy vnější skutečnosti i vnitřního života básnického subjektu jsou (nejčastěji prostřednictvím výrazně hodnotících adjektiv a nápaditých dějových sloves) přiřazovány $\mathrm{k}$ pólům vysokého nebo nízkého. Čtenář přitom není konfrontován s vyzdvihováním jevů běžně považovaných za nízké (chudoba, ošklivost a podobně) k vysokému pólu bytí, a tak se jeho recepční aktivita může soustředit na pozoruhodnou dynamiku významového dění básní, které sugeruje pohyb vzhůru, neustálý neklid lyrického subjektu vybízející čtenáře k duchovnímu růstu. Antické motivy a křestanské symboly dotvářejí sakrální stavbu Országhovy německé poezie, jejíž nejvyšší etáže patří duchovnu, estetičnu a vlastenectví.

Országhova spiritualita se v obrazném systému jeho lyriky projevuje některými protestantskými rysy, které vycházejí z prostorové představivosti duchovních písní Martina Luthera, zejména z jeho nejslavnější skladby Eine feste Burg ist unser Gott (ve slovenském překladu Hrad prepevný je Pán Boh náš). Základní metafora víry - nezničitelné pevnosti je zde postupně rozvíjena řadou dílčích metafor, jejichž smyslem je vyvolávat $\mathrm{v}$ tehdejších posluchačích představy bezpeči a klidu. Básnický mluvčí Országhovy německé lyriky zakouší opakovaně pocity bezpečí v objetí lesa, který je ,zeleným chrámem“ (grüner Dom). Více než barvy jsou však pro básníka důležité zvuky a s nimi spojené různé stupně intenzity větru (od jemného vánku až po silné boư̌e), vysoké hory jsou pak nezbytné jako ukazatel stoupání vzhůru.

Krása tatranské přírody nemá vysokou hodnotu sama o sobě, prochází axiologickým filtrem, hory jsou tak spíše kulisou než přírodním prostředím reálné domoviny. Goethovým a Uhlandovým prostřednictvím osvojené poetologické

7 Podobně „moderně“, to znamená jako moderní drama umělecké existence, lze číst např́klad i slavnou báseň Loreley, v níž Országhův oblíbený básník H. Heine sahá k nápodobě lidové písně a k tragickému př́běhu z lidové pověsti. 
642 charakteristiky bukolického žánru využívá P. Országh k tvořivému estetickému přehodnocování antického dědictví a k propojování hodnot protestantského směru v křest'anství s vlastními, do jisté míry již moderními koncepty básnické tvorby a umělecké existence. Navzdory jazykovým a metrickým nedostatkům zejména počáteční fáze své básnické tvorby v německém jazyce vytváří texty, které se od básnických pokusů postupně posouvají směrem k původní hodnotné umělecké tvorbě.

\section{Pramene}

HVIEZDOSLAV, Pavol Országh, 1931. Sobrané spisy básnické. Zv. 14. Preklady z nemeckých básnikov. Turčiansky Sv. Martin: Matica slovenská.

\section{Literatúra}

GBÚR, Ján, 1998. Hviezdoslav a česká poézia. Prešov: Náuka. ISBN 80-967602-4-6.

LAZAR, Ervín, 1955. Hviezdoslav ako prekladatel' z nemeckej poézie. Slovenská literatúra, roč. 2, č. 4, s. 464-473.

LAZAR, Ervín, 1973. Nemecké básnické pokusy Pavla Országha-Hviezdoslava. In Literárny archív 10/73. Pramene a dokumenty. Martin: Matica slovenská, s. 265-297.

MIKULA, Valér, 1997. Od baroka k postmoderne: interpretačné sondy do slovenskej literatúry. Levice: Vydavatel'stvo L. C. A. ISBN 80-88897-07-6.

PETRAŠKO, L'udovít, 1975. Interpretácia nemeckej poézie P. O. Hviezdoslava. In P. O. Hviezdoslav. Text a kontext. Dolný Kubín: Literárne múzeum P. O. Hviezdoslava - Nitra: Kabinet literárnej komunikácie a experimentálnej metodiky Pedagogickej fakulty, s. 149-158.

PRAŽÁK, Albert, 1955. S Hviezdoslavom. Rozhovory s básnikom o živote a diele. Preložil Gabriel Rapoš. Bratislava: Slovenské vydavatel'stvo krásnej literatúry.

ŠMATLÁK, Stanislav, 1961. Hviezdoslav. Zrod a vývin jeho lyriky. Bratislava: Slovenské vydavatel'stvo krásnej literatúry.

ŠMATLÁK, Stanislav, 1979. Dve storočia slovenskej lyriky. Bratislava: Tatran.

ŠMATLÁK, Stanislav, 1999. Dejiny slovenskej literatúry II. Bratislava: Národné literárne centrum. TURČÁNY, Viliam, 1960. K poetike Hviezdoslavových prekladov. Slovenská literatúra, roč. 7, č. 4, s. 413-438.

TURČÁNY, Viliam, 1961. K poetike Hviezdoslavových prekladov. Slovenská literatúra, roč. 8, č. 1, s. 38-46.

ZELENKOVÁ, Anna, 2017. K nálezu básnických rukopisov Pavla Országha Hviezdoslava. Slavica Litteraria, roč. 20, č. 2, s. 49-57. ISSN 1212-1509.

\section{Internetové zdroje}

Käsmark/Kežmarok. In Online-Lexikon zur Kultur und Geschichte der Deutschen im Östlichen Europa. Dostupné online: http://www.bkge.de/BKGE/MitarbeiterInnen/Wissenschaftlich/Weber

Doc. Dr. Petr Kučera, Ph.D.

Katedra germanistiky a slavistiky

Filozofická fakulta Západočeské

univerzity v PIzni

Riegrova 11

30614 Plzeň

Česká republika

E-mail: pekucera@kgs.zcu.cz 